\title{
Performance of Irrigation Systems under Water Salinity in Wheat Production
}

\author{
Mansour, H. A. and M. Abd El-Hady \\ (*) Water Relations and Field Irrigation Dept., Agric. Division, NRC, Egypt.
}

\begin{abstract}
Use of saline water in irrigated agriculture, as a means of its disposal, was evaluated on a field experiment that conducted in season (2012/2013) at sites of NRC farm, Nubaria, Behaira Governorate to study the effect of saline water injected rates $(0,15$ and $30 \%)$ under surface drip $(S D)$, subsurface drip at $10\left(S S D_{10}\right)$ and $20 \mathrm{~cm}\left(S S D_{20}\right)$ at soil depth on vegetative growth, yield and water use efficiency (WUE) of wheat crop (Triticum aestivum L. cv. Gemmaiza 9). The experiment design was randomized complete block in two factors. Results showed that irrigation systems, $S S D_{20}$, has a promotive effect on the both wheat grain and straw yield, and the percentage of the increase was 6.9 and $5.7 \%$, respectively as compared with SD irrigation system. While the percentage of the increase was 1.7 and $1.8 \%$ comparing $S S D_{10}$ with SD irrigation system for grain and straw yield, respectively. According to the saline irrigation water effect, data noticed that increasing water salinity rate associated with decreasing in wheat yield of both grain and straw and the reduction percentage were 38.5 and 40.0 in same sequences comparing $30 \%$ saline water with $0 \%$., while $15 \%$ saline water decrease yield of grain and straw by about 16.5 and $16.1 \%$, respectively. That is, even though the field appears to have plenty of moisture, the plants wilt because the roots are unable to absorb the water. Increasing water salinity at $15 \%$ reduced WUE of wheat grain and straw by about 11.6 and $16.2 \%$ and the reduction were 37.5 and $39.8 \%$ at saline water $30 \%$ for same sequences. Responses of wheat growth to water deficits vary depending on wheat species and growth stages. Highly positive correlation's coefficient was attained among wheat plant characters, except with water consumptive during growing season of wheat plant. Water consumptive was negatively correlated with the other studied wheat plant characters.
\end{abstract}

Key words: Saline water, Irrigation systems, Wheat, Water use efficiency

\section{Introduction}

Water scarcity is becoming one of the major limiting factors for sustainable agriculture in the semi-arid regions of the world. Not only fresh water, but also wheat production is not enough. Consequently, saline water for deficit irrigation has to be taken into account. Increased agricultural production has become an urgent requirement of the expanding world population (Chen et al., 2011). Yet, there has been a continued decrease in available fresh water that can be used by agricultural production (Cai and Rosegrant, 2003). At the same time, the quality of irrigation water has also deteriorated.

According to soil salinity, wheat is classified to be salt tolerant (Katerji et al., 2000). Khosla and Gupta (1997) found that wheat height and yield increased with irrigation amount under drained conditions, but they were decreased under poor drained conditions. Datta et al. (1998) reported that yields decreases with the rise in irrigation quantity under saline conditions.Saline water has been used successfully for agricultural irrigation (Abd El-Hady and Ebtisam El-dardiry, 2005; Ould Ahmed et al., 2007). Crop yield is the most important consideration in the utilization of saline water (Malash et al., 2005).

Subsurface drip irrigation systems may increase water use efficiency (WUE) due to reduced soil and plant surface evaporation and because only the root zone or the partial root zone is irrigated as opposed to sprinkler irrigation where the entire field area is wetted (Mansour et al., 2010 and Mansour et al., 2014).

Crop growth parameters and yield under combined deficit and saline water irrigation were different to those under separate deficit or saline irrigation. Ayers and Westcot (1985) reported that the combination of drought and salinity reduced the water availability for crops at a more significant rate than the separate effect of either salinity or drought alone.According to Hachicha et al. (2006), salt accumulates on the soil surface before migrate and reach the root zone when drip irrigation is used. Subsurface drip irrigation has been developed to improve salinity management and water use efficiency. Phene et al. (1991) and Oron et al. (1998), reported that surface drip irrigation decreases the accumulation of salts at the root zone level of plants, producing an improved yield and fruit quality.

The objectives of the current study is the effect of different types of drip irrigation system and different water saline degrees by mixing fresh and saline water amounts on vegetative growth, yield, straw and WUE of wheat crop. 


\section{Materials And Method}

field experiments were conducted in season (2012/2013) at sites of NRC Farm (according to the cultivation periods), Nubaria, Behaira Governorate, the study area located to the west of the Nile Delta between latitudes $30^{\circ} 31^{\prime} 44^{\prime \prime} \& 30^{\circ} 36^{\prime} 44^{\prime \prime} \mathrm{N}$ and longitudes $30^{\circ} 20^{\prime} 19^{\prime \prime} \& 30^{\circ} 26^{\prime} 50^{\prime \prime} \mathrm{E}$ to study the effect of different types of drip irrigation system and different water saline degrees by mixing fresh and saline water amounts on vegetative growth, yield, straw and WUE of wheat crop (Triticum aestivum L. cv. Gemmaiza 9).

Experimental soil is sandy loam in texture, poor in organic matter $(1.3 \%)$ and $\mathrm{CaCO}_{3}(3.8 \%)$. In addition to the soil reaction ( $\mathrm{pH} 8.2$ ), soil is non-saline ( $2.6 \mathrm{dSm}^{-1}$ of the extracted soil paste). Soil water content at field capacity and wilting point were 12.6 and $4.7 \%$ on weight basis, which carried out after (Klute, 1986).

The experiment design was randomized complete block in two factors with three replicates. The area of the experimental plot was $12 \times 14 \mathrm{~m}^{2}$ (0.04 feddan). Farm- yard manure had been added at the rate of $10 \mathrm{~m}^{3} \mathrm{fed}^{-1}$ was thoroughly mixed with $0-30 \mathrm{~cm}$ of the surface soil layer before planting in addition to $100 \mathrm{~kg}$ superphosphate $\mathrm{fed}^{-1}\left(15.5 \% \mathrm{P}_{2} \mathrm{O}_{5}\right)$ and $50 \mathrm{~kg}$ potassium sulphate $\left(48 \% \mathrm{~K}_{2} \mathrm{O}\right)$. As well as addition recommended dose of nitrogen $\left(100 \mathrm{~kg} \mathrm{~N}^{-1} \mathrm{fed}^{-1}\right)$ in two equal doses, 4 and 10 weeks after completely germination. Wheat (Triticum aestivum L. cv. Gemmaiza 9) was sown at 10 November. Wheat plants were harvested and separated into grains and straw.

Two factors under study as follows: i) irrigation methods, surface drip (SD), subsurface drip at $10 \mathrm{~cm}$ soil depth $\left(\mathrm{SSD}_{10}\right)$ and subsurface drip $20 \mathrm{~cm}$ at soil depth $\left(\mathrm{SSD}_{20}\right)$, and ii) injected saline irrigation water ratio $(0,15$ and $30 \%)$. Characteristics of the investigated irrigation waters were two wells on of them are saline (Table 1)

Table 1. Chemical characteristics of irrigation water treatments.

\begin{tabular}{|c|c|c|c|c|c|c|}
\hline Parameters & Saline water & Fresh water & $\begin{array}{c}\text { Saline water } \\
15 \%\end{array}$ & $\begin{array}{c}\text { Saline water } \\
30 \%\end{array}$ & $\begin{array}{c}\text { Standard } \\
\text { deviation }\end{array}$ & $\begin{array}{c}\text { Standard } \\
\text { error }\end{array}$ \\
\hline $\mathrm{EC}(\mathrm{dS} / \mathrm{m})$ & 8.83 & 1.68 & 2.47 & 3.59 & 3.2 & 1.6 \\
\hline $\mathrm{pH}$ & 7.6 & 7.3 & 7.3 & 7.4 & 0.1 & 0.1 \\
\hline $\mathrm{TDS}(\mathrm{ppm})$ & 7064 & 1075 & 1974 & 2872 & 2648 & 1324.4 \\
\hline $\mathrm{Ca}$ & 15.3 & 5.3 & 6.4 & 7.6 & 4.5 & 2.3 \\
\hline $\mathrm{Mg}$ & 11.3 & 4.6 & 4.6 & 5.7 & 3.2 & 1.6 \\
\hline $\mathrm{Na}$ & 60.2 & 6.8 & 13.5 & 22.4 & 23.9 & 11.9 \\
\hline $\mathrm{K}$ & 0.2 & 0.1 & 0.2 & 0.2 & 0.1 & 0.0 \\
\hline $\mathrm{HCO}_{3}{ }^{-}$ & 0.10 & 0.0 & 0.0 & 0.0 & 0.1 & 0.0 \\
\hline $\mathrm{HCO}_{3}{ }^{-}$ & 6.5 & 2.3 & 3.1 & 3.5 & 1.8 & 0.9 \\
\hline $\mathrm{Cl}^{=}$ & 66.4 & 9.1 & 15.2 & 24.3 & 25.9 & 12.9 \\
\hline $\mathrm{SO}_{4}{ }^{-}$ & 15.3 & 5.4 & 6.4 & 8.1 & 4.5 & 2.2 \\
\hline $\mathrm{SAR}$ & 16.5 & 3.1 & 5.8 & 8.7 & 5.8 & 2.9 \\
\hline
\end{tabular}

TDS: total dissolved salts

Soluble salts that accumulate in soils must be leached below the crop root zone to maintain productivity so leaching requirement was took place according to the soil and irrigation water salinity.

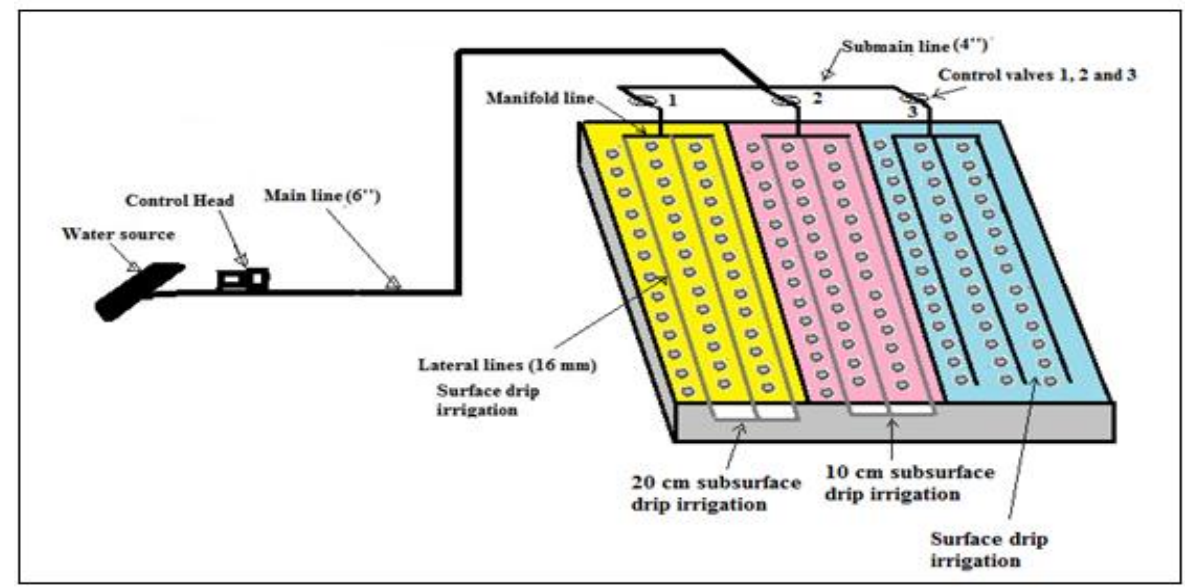

Fig. (1) Layout of drip surface and subsurface irrigation systems. 
Irrigation water amounts were estimated using the reference evapotranspiration and crop coefficients after (Allen et al, 1998 and FAO, 1998) while the irrigation timing was determined using a water balance, a common practice among.

Calculated amount of water requirements was (472.8, 445.8; $418.1 \mathrm{~mm}$ season $^{-1}$ ) 1985.7, 1872.5; 1756.2 under $\mathrm{SD}, \mathrm{SSD}_{10} ; \mathrm{SSD}_{20} \mathrm{~m}^{3} \mathrm{fed}^{-1}$ season $^{-1}$, respectively.

Table (2) Water requirements for wheat crop at NRC farm, Nubaria sites, Egypt.

\begin{tabular}{|c|c|c|c|c|c|c|}
\hline Month & Dec & Jan & Feb & March & April & May \\
\hline ET (mm/day) & 2.8 & 6.3 & 5.9 & 4.2 & 7.4 \\
\hline Kc & 0.4 & 0.4 & 0.8 & 1.3 & 0.5 & 0.4 \\
\hline ETc(mm/day) & 1.1 & 2.5 & 4.7 & 5.4 & 3.7 & 0.8 \\
\hline Growth stage & $\begin{array}{c}\text { Planting } \\
\text { (Establishment) }\end{array}$ & \multicolumn{2}{|c|}{$\begin{array}{c}\text { Rapid vegetative } \\
\text { growth }\end{array}$} & $\begin{array}{c}\text { Flowering seed } \\
\text { fill }\end{array}$ & \multicolumn{2}{c|}{ Maturity and harvesting } \\
\hline IRg (mm/month) & 36.4 & 85.3 & 150.0 & 184.4 & 122.0 & 27.4 \\
\hline IRg (mm/month) & 33.1 & 77.6 & 136.4 & 167.5 & 111.1 & 24.9 \\
\hline
\end{tabular}

Field water use efficiency (FWUE): It was calculated as follows (Michael, 1978).

$\mathrm{FWUE}=\mathrm{Y} / \mathrm{WR}$

Where:

$\mathrm{Y}=$ Seed yield $\left(\mathrm{kg} / \mathrm{fed}^{-1}\right)$

$\mathrm{WR}=$ The total amount of water applied in the field $\left(\mathrm{m} 3 / \mathrm{fed}^{-1}\right)$.

Crop water use efficiency (CWUE): It was calculated as follows (Michael, 1978).

CWUE $=$ Y/WCU

Where:

$\mathrm{Y}=$ Seed yield $\left(\mathrm{kg} \mathrm{fed}^{-1}\right)$ and $\mathrm{WR}=$ Actual water consumptive use $\left(\mathrm{m}^{3} \mathrm{fed}^{-1}\right)$.

Treatments were triplicated in randomized complete block design after (Steel and Torrie, 1980) and means were compared after LSD at 5\%. Correlations and regression analysis were carried out among studied variables after using SAS (2001).

\section{Irrigation water treatments properties}

\section{Results And Discussions}

Data on table (1) illustrated chemical properties of the irrigation water treatments. Data noticed that saline water was higher in total dissolved salts and its value was about 7 fold over fresh one. According to the SAR values of the irrigation water treatments, saline water has a high SAR value (16.5) which located in Table (3) recognized by medium (relative to the sodium hazardous of water) after Fipps (2003). However, SAR values of the fresh irrigation water and the others two saline mixing ratios were 3.1, 5.8 and 8.7, they have low sodium hazard of water (Table 3). Also, one can notice that increasing saline water ratio in irrigation water was associated with the increase in $\mathrm{Ca}+\mathrm{Mg}$ ions that play an important role in control of SAR value, despite $\mathrm{Na}^{+}$was increased. In addition to the obtained results, increasing $\mathrm{Ca}+\mathrm{Mg}$ and/or $\mathrm{SO}_{4}$ ions had improved irrigation water properties.

Table 3. The sodium hazard of water based on SAR values.

\begin{tabular}{|c|c|l|}
\hline \multirow{2}{*}{ SAR value } & \multicolumn{2}{|c|}{ Concentration, total dissolved solids } \\
\cline { 2 - 3 } & Sodium hazard of water & \multicolumn{1}{c|}{ Comments } \\
\hline $1-10$ & Low & Use on sodium sensitive crops such as avocados must be cautioned. \\
\hline $10-18$ & Medium & Amendments (such as Gypsum) and leaching needed. \\
\hline $18-26$ & High & Generally unsuitable for continuous use. \\
\hline$>26$ & Very High & Generally unsuitable for use. \\
\hline
\end{tabular}

Leaching is the basic management tool for controlling salinity. Water is applied in excess of the total amount used by the crop and lost to evaporation. The strategy is to keep the salts in solution and flush them below the root zone. The amount of water needed is referred to as the leaching requirement or the leaching fraction.

This experiment was carried out to maximize utilization of saline water in wheat production without risk on soil and/or irrigation systems. So, injection of saline water through irrigation system has a priority to avoid highly cost to set up basin for mixing, avoid the mistake in mixing ratio and to avoid conveying saline water through the field.

The highest values of the examined wheat plant characters were recorded in $\mathrm{SSD}_{20}$ with $0 \%$ saline water and the lowest one was attained at SD irrigation system with $30 \%$ saline water. Obtained results (Table 2) showed that $\mathrm{SSD}_{20}$ was superior for improving wheat plant characters such as no. of spike $/ \mathrm{m}^{2}$, seed index $(1000$ 
grain weight), peduncle length and plant height. Also, it could be arranged the examined irrigation systems values for the studied plant characters in descending order as follow: $\mathrm{SSD}_{20}>\mathrm{SSD}_{10}>\mathrm{SD}$ for all studied wheat plant characters. Slightly increase in the abovementioned plant characters and the change percentage was 1.0, 3.0, 5.3, and $1.8 \%$ in same sequences.

Regardless drip irrigation systems, increased saline water rate led to decrease in all studied parameters and the reduction \% were 7.0,23.4, 19.3 and $9.7 \%$ for No. of spike $/ \mathrm{m}^{2}$, seed index, peduncle length and plant height. The main potential effect of plant characters resulted from saline water is seed index $(-23.4 \%)$ that pointed out to the quality of final product. However, excess water may be applied every irrigation to provide the water needed for leaching. However, the time interval between leaching does not appear to be critical provided that crop tolerances are not exceeded. Also to mentioned that the plant height is an index to straw yield which used mainly in animal feeding.

\section{Yield and its components}

Regarding to the investigated irrigation systems, $\mathrm{SSD}_{20}$ has a promotive effect on the both wheat grain and straw yield, and the percentage of the increase was 6.9 and $5.7 \%$, respectively comparing with SD irrigation system. While the percentage of the increase was 1.7 and $1.8 \%$ comparing $\mathrm{SSD}_{10}$ with SD irrigation system for grain and straw yield, respectively.

According to the saline irrigation water effect, data noticed that increasing water salinity rate associated with decreasing in wheat yield of both grain and straw and the reduction percentage were 38.5 and 40.0 in same sequences comparing $30 \%$ saline water with $0 \%$., while $15 \%$ saline water decrease yield of grain and straw by about 16.5 and $16.1 \%$, respectively. That is, even though the field appears to have plenty of plants. Data in table (4) illustrated the effect of drip irrigation systems and rate of saline water injected in irrigation system on No of spike/ $\mathrm{m}^{2}, 1000 \mathrm{kernel}$ weight, Peduncle length, water consumptive WC, Yield, and water use efficiency WUE.

Table (4) Effect of different drip irrigation systems and different saline water on wheat vegetative growth and yield.

\begin{tabular}{|c|c|c|c|c|c|c|c|c|c|c|}
\hline \multirow{2}{*}{$\begin{array}{l}\text { Drip irrigation } \\
\text { systems }\end{array}$} & \multirow{2}{*}{$\begin{array}{c}\begin{array}{c}\text { Saline water } \\
\text { ratio to fresh } \\
\text { water }\end{array} \\
(\%)\end{array}$} & \multirow[t]{2}{*}{$\begin{array}{c}\text { No of } \\
\text { Spike/m } \mathbf{m}^{2}\end{array}$} & \multirow{2}{*}{$\begin{array}{c}\begin{array}{c}1000 \\
\text { grain } \\
\text { Weight }\end{array} \\
\text { (g) }\end{array}$} & $\begin{array}{c}\text { Peduncle } \\
\text { length }\end{array}$ & $\begin{array}{c}\text { Plant } \\
\text { Height }\end{array}$ & \multirow{2}{*}{$\frac{\text { WC }}{\mathrm{m}^{3} / \mathrm{fed}}$} & \multicolumn{2}{|c|}{ Yield (kg/fed) } & \multicolumn{2}{|c|}{ WUE (kg/m3) } \\
\hline & & & & \multicolumn{2}{|c|}{ (cm) } & & Grain & Straw & Grain & Straw \\
\hline \multirow{4}{*}{ SD } & 0 & 547 & 32.5 & 33.4 & 97.6 & 1985.7 & 3350.2 & 2898.7 & 1.69 & 1.46 \\
\hline & 15 & 536 & 30.2 & 31.3 & 95.4 & & 2564.6 & 2254.4 & 1.29 & 1.14 \\
\hline & 30 & 502 & 24.6 & 26.2 & 83.6 & & 1836.7 & 1594.6 & 0.92 & 0.80 \\
\hline & Mean & 528.3 & 29.1 & 30.3 & 92.2 & & 2583.8 & 2249.2 & 1.30 & 1.13 \\
\hline \multirow{4}{*}{$\mathrm{SSD}_{10}$} & 0 & 551 & 33.6 & 35.7 & 99.7 & 1872.5 & 3488.9 & 3013.2 & 1.86 & 1.61 \\
\hline & 15 & 548 & 31.7 & 33.8 & 98.2 & & 2964.2 & 2523.4 & 1.58 & 1.35 \\
\hline & 30 & 514 & 26.4 & 28.9 & 92.6 & & 2187.3 & 1833.3 & 1.17 & 0.98 \\
\hline & Mean & 537.7 & 30.6 & 32.8 & 96.8 & & 2880.1 & 2456.6 & 1.54 & 1.31 \\
\hline \multirow{4}{*}{$\mathrm{SSD}_{20}$} & 0 & 554 & 35.9 & 38.4 & 102.6 & 1756.2 & 3524.3 & 3102.5 & 2.00 & 1.76 \\
\hline & 15 & 550 & 33.4 & 36.2 & 99.8 & & 3125.2 & 2789.2 & 1.78 & 1.58 \\
\hline & 30 & 520 & 27.1 & 31.6 & 94.6 & & 2435.2 & 1978.2 & 1.38 & 1.13 \\
\hline & Mean & 554 & 32.1 & 35.4 & 99.0 & & 3028.2 & 2623.2 & 1.72 & 1.49 \\
\hline \multicolumn{2}{|c|}{ LSD 5\% } & 12.5 & 1.4 & 1.8 & 2.5 & & 180.5 & 120.5 & 0.20 & 0.14 \\
\hline \multicolumn{2}{|c|}{ Interaction } & 10.2 & 0.9 & 1.3 & 2.1 & & 188.3 & 160.6 & 0.15 & 0.08 \\
\hline
\end{tabular}

SD: Surface drip, SSD10: Sub-surface drip with $10 \mathrm{~cm}$ soil depth, SSD20: Sub-surface drip with 20cm soil depth, FW: Fresh water, and SW: Saline water.

The maximum and minimum of grain and straw yield were $\mathrm{SSD}_{20}(0 \%$ saline water) and $\mathrm{SD}(30 \%$ saline water). Also, one can notice that the increase in saline water rate inside irrigation system treatments associated with reduction in values of the studied. Same trend was obtained in seed index, where using $\mathrm{SSD}_{20}$ improved seed index by about $12 \%$ comparing with SD irrigation system. The percentage of reduction in seed index resulted from using saline water at $30 \%$ was $21.7 \%$.

Shani and Dudley (2001) and Ragab et al (2008) mentioned that the maximum yield and the corresponding irrigation water quantity for poor quality water were less than those for good quality water. Therefore, crop growth under deficit irrigation with saline water should be further investigated. Also, AbdelHady et al. (2011) mentioned that soil has a potential effect on the using saline water in irrigation and avoid risks to its properties depend mainly on the determination these properties especially hydrophysical ones.

According to the water use efficiency (WUE), the highest and lowest values of WUE of grain and straw were recorded under $\mathrm{SSD}_{20}$; $\mathrm{SD}$ after using saline water at rate 0 and $30 \%$, respectively. Regarding to the effect of investigated irrigation systems on WUE of wheat grain and straw, their values were increased by about 12 and $11 \%$ comparing with SD irrigation system, respectively. While the change for WUE of wheat grain and straw was $4.4 \%$ comparing $\mathrm{SSD}_{20}$ with SD irrigation system. Whereas, increasing water salinity at 15 $\%$ reduced WUE of wheat grain and straw by about 11.6 and $16.2 \%$ and the reduction were 37.5 and $39.8 \%$ at saline water $30 \%$ for same sequences. Responses of wheat growth to water deficits vary depending on wheat 
species and growth stages. Jalota et al. (2006) reported that the thesis to grain development period is the most sensitive stage to water stress in wheat in Northwest India. Zhang et al. (2006) reported that water stress should be avoided at the booting and heading of spring wheat. In addition, growth parameters have manifested certain differences during deficit irrigation.

Generally, an appropriate deficit irrigation system with fresh water can increase irrigation efficiency without significantly decreasing yield (Mao et al., 2003; Panda et al., 2003).

Table (5) Simple correlation among wheat characters.

\begin{tabular}{|c|c|c|c|c|c|c|c|c|}
\hline & No.Spike & Seed index & $\begin{array}{l}\text { Peduncle } \\
\text { length }\end{array}$ & Plant height & $\begin{array}{l}\text { Water } \\
\text { consumption }\end{array}$ & $\begin{array}{l}\text { Grain } \\
\text { yield }\end{array}$ & $\begin{array}{l}\text { Straw } \\
\text { yield }\end{array}$ & $\begin{array}{l}\text { WUE } \\
\text { grain }\end{array}$ \\
\hline Seed index & $0.962 * *$ & & & & & & & \\
\hline Peduncle length & $0.934 * *$ & $0.955^{* *} *$ & & & & & & \\
\hline Plant height & $0.928 * *$ & $0.921 * *$ & $0.960 * *$ & & & & & \\
\hline Water consumption & -0.399 & -0.390 & $-0.637^{*}$ & -0.583 & & & & \\
\hline Grain yield & $0.940 * *$ & $0.967 * *$ & $0.931 * *$ & $0.911 * *$ & -0.361 & & & \\
\hline Straw yield & $0.944 * *$ & $0.981 * *$ & $0.929 * *$ & $0.895 * *$ & -0.334 & $0.994 * *$ & & \\
\hline WUE grain & $0.930 * *$ & $0.957 * *$ & $0.984 * *$ & $0.945 * *$ & -0.569 & $0.971 * *$ & $0.963 * *$ & \\
\hline WUE straw & $0.939 * *$ & $0.975^{* *}$ & $0.984 * *$ & $0.934 * *$ & -0.538 & $0.972 * *$ & $0.973 * *$ & $0.996^{* *}$ \\
\hline
\end{tabular}

Table (5) illustrated simple correlations coefficient among wheat characters. Data on hand revealed that highly positive correlation's coefficient among wheat plant characters were attained, except with water consumptive during growing season of wheat plant. Water consumptive was negatively correlated with the other studied wheat plant characters not significant number of spike $/ \mathrm{m}^{2}$, seed index, and significant at $5 \%$ with ped length and plant height

\section{It could be concluded that:}

\section{Conclusions}

Regarding to the effect of investigated irrigation systems on WUE of wheat grain and straw, their values were increased by about 12 and $11 \%$ comparing with SD irrigation system, respectively. The increase in saline water rate inside irrigation system treatments associated with reduction in values of the studied. Using $\mathrm{SSD}_{20}$ improved seed index by about $12 \%$ comparing with SD irrigation system. The percentage of reduction in seed index resulted from using saline water at $30 \%$ was $21.7 \%$. Increasing water salinity rate associated with decreasing in wheat yield of both grain and straw and the reduction percentage were 38.5 and 40.0 in same sequences comparing $30 \%$ saline water with $0 \%$., while $15 \%$ saline water decrease yield of grain and straw by about 16.5 and $16.1 \%$, respectively. Finally, the highest values of the examined wheat plant characters were recorded in $\mathrm{SSD}_{20}$ with $0 \%$ saline water and the lowest one was attained at $\mathrm{SD}$ with $30 \%$ saline water.

\section{References}

[1] Abd El-Hady, M. and Ebtisam, I. El-dardiry, 2005. Sandy soils characteristics as affected by irrigation with sewage water. 1-Some physical characteristics and water use efficiency. Egypt.J. Appl. Sci., 20 (7), 288 - 301.

[2] Abdel-Hady, M., I. Ebtisam, El-Dardiry and M.Y. Tayel, 2011. Assessment of some hydrophysical properties for selecting irrigation methods. J. of applied sciences research Journal of Applied Sciences Research, 7(6): 997-1006.

[3] Ali M H, Hoque M R, Hassan A A, et al., 2007. Effects of deficit irrigation on yield, water productivity, and economic returns of wheat. Agricultural Water Management, 92: 151-161.

[4] Allen R. G., L. S. Pereira, D. Raes and M. Smith, 1998. Crop evapotranspiration - Guidelines for computing crop water requirements - FAO Irrigation and drainage paper 56. FAO - Food and Agriculture Organization of the United Nations. Rome.

[5] Ayars J E, Hutmacher R B, Schoneman R A. , S. S. Vail, T. Pflaum, 1993. Long term use of saline water for irrigation. Irrigation Science, 14: 27-34.

[6] Ayers, R.S. and D.W. Westcot, 1985. Water quality for agriculture. Irrigation and Drainage aper No. 29, FAO, Rome. 174 p.

[7] Cetin, O. and L. Bilgel, 2002. Effects of different irrigation methods on shedding and yield of cotton. Agric. Water Manage. 54, 115.

[8] FAO, 1998. Crop evapotranspiration - Guidelines for computing crop water requirements - FAO Irrigation and drainage paper 56. Rome, Italy.

[9] Fipps G., 2003. Irrigation Water Quality Standards and Salinity Management. Texas A\&M Agriculture Extension, B.1667, 4-03.

[10] Hachicha, M., H. Nahdi, S. Rejeb, 2006. Effect de l'irrigation au goutte à goutte outerraine avec l'eau salée sur une culture de piment. Ann. INRAT, 79, 85-103.

[11] Jalota, S. K., A. Sood, G. B .S. Chahal, 2006. Crop water productivity of cotton (Gossypium hirsutum L.) -wheat (Triticum aestivum L.) system as influenced by deficit irrigation, soil texture and precipitation agricultural water management. Agricultural Water Management, 84: 137-146.

[12] Katerji N, M. Mastrorilli, J. W. van Hoorn, 2009. Durum wheat and barley productivity in saline-drought environments. European Journal of Agronomy, 31: 1-9.

[13] Khosla, B. K. and R.K. Gupta, 1997. Response of wheat to saline irrigation and drainage. Agricultural Water Management, 32: 285-291.

[14] Klute, A. 1986. Water retention: Laboratory methods. In A. Klute (ed.), Methods of Soil Analysi, Part1, Physical and mineralogical methods. 635-662, 9 ASA and SSSA, Madison, WI.

[15] Malash N, T. J. Flowers and R. Ragab, 2005. Effect of irrigation systems and water management practices using saline and nonsaline water on tomato production. Agricultural Water Management, 78: 25-38. 
[16] Mansour, H. A., M. S. Gaballah, M. Abd El-Hady and Ebtisam I. Eldardiry, 2014. Influence of different localized irrigation systems and treated agricultural wastewater on distribution uniformities, potato growth, tuber yield and water use efficiency. International Journal of Advanced Research, 2(2):143 - 150. Journal homepage: http://www.journalijar.com.

[17] Mansour, H.A., M. Y. Tayel, M. A. Abd El-Hady, David A. Lightfoot, A. M. El- Gindy, 2010. Modification of water application uniformity among closed circuit trickle irrigation systems. AgricultureY Science journal, 1(1):1-9., http://www.scirp.org/journal/as/

[18] Oron, G., Y. DeMalach, L. Gillerman, I.David and V.P. Rao, 1998. Improved saline - water use under subsurface drip irrigation. Agric. Water Manage. 39, 19-33.

[19] Ould Ahmed B A., T. Yamamoto and V. Rasiah, 2007. The impact of saline water irrigation management options in a dune sand on available soil water and its salinity. Agricultural Water Management, 88: 63-72.

[20] Panda R. K., S .K. Behera and P. S. Kashyap, 2003. Effective management of irrigation water for wheat under stressed conditions. Agricultural Water Management, 63: 37-56.

[21] Phene, C.J., K.R. Davis, R.B. Hutmacher, R.B., B. Yosef, and D.W. Meek, 1991. Effect of high frequency surface and subsurface drip irrigation on root distribution of sweet corn. Irr. Sci. 12, 135-140.

[22] Ragab A.A.M., F.A. Hellal and M. Abd El-Hady, 2008. Water salinity impacts on some soil properties and nutrients uptake by wheat plants in sandy and calcareous soil. Australian Journal of Basic and Applied Sciences, 2(2): 225-233.

[23] Rebecca, B., 2004. Soil Survey Laboratory Methods Manual. Soil Syrvey Investigations Report No. 42 Natural Resources Conservation Services.

[24] SAS Institute, 2001. SAS statistics users' guide. Release 8.2. SAS Institute, Cary, NC.

[25] Steel R.G.D. and J.H. Torrie, 1980. Analysis of covariance, In: Principles and Procedures of Statistics: a Biometrical Approach, pp. 401-437. McGraw-Hill, New York. 